\title{
Ratooning Response of Lowland Rice NSIC Rc352 (Oryza sativa L.) to Method of Nitrogen Application
}

\author{
Dionesio M. Banoc \\ Visayas State University \\ https://orcid.org/0000-0001-2345-6789 \\ dionesio.banoc@vsu.edu.ph
}

\section{Abstract}

This study seeks to determine the effect of $N$ fertilization method on ratoon lowland rice performance, to choose a fertilization method that provides high ratooned yield, and to assess its profitability adopting $N$ fertilization method. The experiment lays out in a Randomized Complete Block Design with three replications and five $N$ fertilization methods as treatments. Method of N application significantly affected the number of days to heading and maturity, plant height, leaf area index (LAl), number of productive tillers hill-1, , panicle length and weight, number of filled and unfilled grains panicle ${ }^{-1}$. This method compensates cost of production of growing ratoon crop than those of the main crop. In fact, the highest profit (PhP25,564.80) was obtained in ratooned plants, which received $60 \mathrm{~kg} \mathrm{ha}^{-1} \mathrm{~N}$ basal + $30 \mathrm{~kg} \mathrm{ha}^{-1} \mathrm{~N}$ topdress application $\left(T_{3}\right)$ due to higher grain yield. Thereby, this is an appropriate option that provides high productivity and income for the ratoon growers.

Keywords: lowland rice, basal, fertilization, ratoon, topdress

\subsection{Introduction}

Rice (Oryza sativa L.) is an annual crop and is considered the staple food in the Philippines and worldwide. It ranks second relative to area harvested and first concerning its significance as food crop. $40 \%$ of the world's populations are estimated to depend on rice as a source of calories. Filipinos generally rely on rice as their primary food source compared to other crops (Samson, 1980).

Rice shortage is becoming a problem in the country due to the rapid increase in population. This constraint is becoming the worst through irrigation problems where rice cropping cannot be appropriately adopted. One problem encountered even in well-irrigated lowland rice areas is limited capital, which makes it difficult for farmers to sustain the cost of farm operations in adopting the recent farm technologies for higher crop productivity. In this regard, ratooning can be the best option to maximize the cropping period in 
addition to less input costs needed. Rice ratooning is seen as a practical measure in increasing rice production per unit area per unit time due to the shorter growth duration of the ratoon crop than the main crop (Samson, 1980). Baňoc et al. (2020) confirmed that ratoon crop matured from 45 to 90 days, depending on the cutting height wherein shorter cutting height of ratoon crop dovetailed shorter growth duration (45-55 days) while longer cutting height extended up to 60 - 80 days after harvesting of the main crop. However, growth period of the main crop using NSIC Rc352 matures from 112-115 days from sowing. The practice of ratooning eliminates expenses for land preparation, seedbed preparation, planting, and seed materials. Further, the water requirement for the ratoon crop is $60 \%$ lower than the main crop (Elias, 1969), and the labor needed is only $50-60 \%$. However, limited farmers have been practicing ratoon cropping due to insufficient technical information available to improve the practice (Plucknett et al., 1970).

The vital nutrients needed for plant growth are the macronutrient elements, particularly $\mathrm{N}$, $\mathrm{P}$, and $\mathrm{K}$. Among the three, nitrogen is the most limiting since it is highly mobile that can easily be leached, affected by seepage and run-off. In this context, timing and rates of $\mathrm{N}$ fertilization is an utmost consideration. Nitrogen (N) is the most yield-limiting nutrient in lowland rice production. Nitrogen deficiencies are widely occurring in lowland rice soils (Fageria \& Baligar, 1996; Kundu et al., 1996). Aulakh et al. (2000) mentioned that flooded rice responded to an increase in $\mathrm{N}$ rates up to $120 \mathrm{~kg} \mathrm{~N} \mathrm{ha}^{-1}$. Fernandez (1991) claimed that higher levels of $\mathrm{N}$ fertilizer application, resulting in significantly taller plants and more productive grains. However, $\mathrm{N}$ fertilizer is one of the most expensive inputs for rice production. Hence, proper $\mathrm{N}$ management is essential for optimizing rice grain yields (Fageria, Baligar, \& Jones, 1997).

Method of $\mathrm{N}$ fertilizer application is one of the practices that can increase $\mathrm{N}$ utilization efficiency. Fertilizer application, especially $\mathrm{N}$, at the right amount and at the right time minimizes losses and provides an adequate supply of $\mathrm{N}$ when rice plant needs it most. Excessive use of $\mathrm{N}$ fertilizers decreases $\mathrm{N}$ utilization efficiency (NUE), and it also increases $\mathrm{N}$ losses to the environment through soil erosion, leaching, ammonia volatilization, and $\mathrm{N}_{2} \mathrm{O}$ emission, causing pollution in the atmosphere through its water systems (Zhu and Chen, 2002). Inadequate nitrogen results in the pale color of leaves, reduced tillering (Clatterbuck, 1914), and disturbed normal cell division and decreased rate of protein synthesis (Castillejo et al., 2010). However, to overcome the abovementioned problems, one of the $\mathrm{N}$ management practices is applying the right amount at the right time. The result implies that splitting of $\mathrm{N}$ rates into two or more applications is the best strategy to determine the appropriate method that will give optimum growth and yield of ratoon lowland rice. This study aims to assess the effect of the method of $\mathrm{N}$ fertilization on the development and yield performance of ratoon lowland rice, to determine the appropriate method of nitrogen application that would give an optimum yield of ratoon lowland rice, and to assess the cost and return of ratooning lowland rice as influenced by the different methods of nitrogen fertilizer application.

\subsection{Materials and Methods}

This study which aimed mainly at the production of ratoon crop, wherein plant stubbles 
were cut uniformly to a height of three inches from the main plants in all treatment plots. After harvesting the main plant, five soil samples were collected separately from each treatment plot. Then, composited, air dried, pulverized, and sieved using $2 \mathrm{~mm}$ wire mesh. The collected samples did for the determination of soil $\mathrm{pH}, \%$ organic matter, total N, P, and K. Another set of samples were processed for soil analysis from each treatment plot right after harvesting of the ratoon crop. These were processed, composited per replication, and analyzed for the determination of the same soil parameters mentioned above to represent the final soil analysis.

The experimental design adopted was in a Randomized Complete Block Design (RCBD) with five treatments and three replications. The individual plot measured the 10.0 sq. m. at $5.0 \mathrm{~m} \mathrm{x}$ $2.0 \mathrm{~m}$ with ten rows per treatment plot consisting of 250 hills. Replication and treatment plots were arranged separately by $1.0 \mathrm{~m}$ and $0.75 \mathrm{~m}$ alleyways, respectively, to facilitate farm operation and data gathering. The different treatments designated in the experiment are as follows: $T_{0}=$ No fertilizer application (Control), $\mathrm{T}_{1}=90 \mathrm{~kg} \mathrm{ha}^{-1} \mathrm{~N}$ topdress application only, $\mathrm{T}_{2}=30 \mathrm{~kg} \mathrm{ha}^{-1} \mathrm{~N}$ basal $+60 \mathrm{~kg} \mathrm{ha}^{-1}$ $\mathrm{N}$ topdress application, $\mathrm{T}_{3}=60 \mathrm{~kg} \mathrm{ha}^{-1} \mathrm{~N}$ basal +30 $\mathrm{kg} \mathrm{ha}^{-1} \mathrm{~N}$ topdress application and $\mathrm{T}_{4}=90 \mathrm{~kg} \mathrm{ha}^{-1} \mathrm{~N}$ basal application only.

The experiment used an irrigated lowland inbred rice variety - NSIC Rc352 (Tubigan 27). This variety is an early-maturing, high-yielding, intermediate amylose content, intermediate reaction to pests and diseases, and excellent grain quality like IR74 and IR64.
The amount of fertilizer applied in the main plants adopted a 90-60-60 kg ha-1 $\mathrm{N}_{1} \mathrm{P}_{2} \mathrm{O}_{5}$, and $\mathrm{K}_{2} \mathrm{O}$. For the ratoon crop however, urea was applied ten days after harvesting the main plants in $T_{2}, T_{3}$ and $\mathrm{T}_{4}$ treatment plots except for $\mathrm{T} 0$ as specified in Table 1. Topdressing of $\mathrm{N}$ fertilizer was done at the panicle initiation stage, particularly in treatments; $T_{1}, T_{2}$, and $T_{3}$. Topdress application was done when panicles developed and grew into a white feathery cone, creating a bulge at the base of the leaf sheath that sometimes referred to as the green ring stage in rice. It was a thin green band that was visible just above the node and represented the very beginning of internode elongation.

The ratoon crop was hand-weeded four weeks after harvesting of the main plant. The subsequent operations were done when weeds emerged until the plant canopy closed in. Irrigation was done right after harvesting the main plant at a depth of about three to five $\mathrm{cm}$. Intermittent irrigation was started 14 days after regrowth of the foresaid crop and continued until two weeks before harvesting of the ratoon crop. Spraying of pesticides in controlling insect pests and diseases was adopted while eliminating rodents with the use of Coumatetralyl rodenticide $(0.75 \%)$, which was performed two weeks after harvesting of the main plants.

During the harvesting, a sharp sickle was used when $90 \%$ of the panicles in each treatment plot had ripened as indicated by firmness and ambercolored grains. The harvestable area used in the main plants was similar in the ratoon crop. Then, the protocol of harvesting, as well as threshing, sun drying, and cleaning employed in the main plants, was adopted. 
Table 1. Amount of inorganic fertilizer applied per treatment plot for the ratoon crop

\begin{tabular}{|c|c|c|}
\hline \multirow[t]{2}{*}{ Treatment } & \multicolumn{2}{|c|}{$\begin{array}{l}\text { Amount of urea } \\
(46-0-0) \text { fertilizer } \\
\text { applied per plot }(\mathrm{g})\end{array}$} \\
\hline & Basal & Topdress \\
\hline $\begin{aligned} \mathrm{T}_{0}= & \text { No fertilizer } \\
& \text { application (Control) }\end{aligned}$ & 0 & 0 \\
\hline $\begin{aligned} \mathrm{T}_{1}= & 90 \mathrm{~kg} \mathrm{ha}^{-1} \mathrm{~N} \text { topdress } \\
& \text { application only }\end{aligned}$ & 0 & 195.65 \\
\hline $\begin{array}{r}\mathrm{T}_{2}=30 \mathrm{~kg} \mathrm{ha-1} \mathrm{N} \text { basal }+ \\
60 \mathrm{~kg} \mathrm{ha}^{-1} \mathrm{~N} \text { topdress }\end{array}$ & 65.22 & 130.43 \\
\hline $\begin{array}{r}\mathrm{T}_{3}=60 \mathrm{~kg} \mathrm{ha}-1 \mathrm{~N} \text { basal }+ \\
30 \mathrm{~kg} \mathrm{ha}^{-1} \mathrm{~N} \text { topdress }\end{array}$ & 130.43 & 65.22 \\
\hline $\begin{aligned} \mathrm{T}_{4}= & 90 \mathrm{~kg} \mathrm{ha}^{-1} \mathrm{~N} \text { basal } \\
& \text { application only }\end{aligned}$ & 195.65 & 0 \\
\hline
\end{tabular}

\subsection{Agronomic and yield and yield components gathered}

The agronomic characteristics gathered were relative to the number of days from harvesting the main plant to heading and harvesting of the ratoon crop, plant height $(\mathrm{cm})$ at heading, leaf area index (LAl), and fresh straw yield $\left(\mathrm{t} \mathrm{ha}^{-1}\right)$. However, data gathered on yield and yield component parameters relative to the number of productive tillers hill $^{-1}$, panicle length $(\mathrm{cm})$ at maturity, panicle weight $(\mathrm{g})$, number of filled and unfilled grains panicle-1, the weight of 1,000 seeds (g), and grain yield (t ha-1) were done. Harvest index, cost and return analysis of ratoon crop, meteorological data, use of Statistical Tool for Agricultural Research (STAR) for the analysis of variance (ANOVA), and the comparison of treatment means through Tukey's Studentized Range (HSD) were also adopted.

\section{Data Gathered}

\section{Agronomic Characteristics}

1. The number of days from harvesting the main plant to heading. This was determined by counting the number of days from harvesting of the main plant up to the time, when $50 \%$ of the panicles of ratooned crop had been fully exerted from the flag leaf sheath in each treatment plot.

2. The number of days from harvesting the main plant to harvesting of the ratooned crop. This was determined by counting the number of days from harvesting of the main plant up to $90 \%$ maturity of the ratooned crop in each treatment plot.

3. Plant height $(\mathrm{cm})$ at heading. This was determined by measuring ten sample plants in each treatment plot from the ground level up to the tip of the tallest part of the plant at the heading of ratooned crop.

4. Leaf Area Index (LAI). This was determined at heading stage by measuring the length and width of all the leaves from the middle tiller of five sample hills in each treatment plot (Gomez, K. A. \& Gomez, A.A., 1976). The length and width of each leaf was multiplied by the correction factor of 0.75 (Yoshida, 1981). The mean was then multiplied by the total number of tillers per hill. The total leaf area of the five sample hills was divided by the ground area occupied by the five samples as shown in the formula:

$$
L A I=\frac{\text { Total Leaf Area (five hills) }}{\begin{array}{c}
\text { Ground area covered by five } \\
\text { hills }\left(2,000 \mathrm{~cm}^{2}\right)
\end{array}}
$$


where:

Leaf Area $=$ length $\mathrm{x}$ width $\mathrm{x}$ correction factor (0.75)

Total leaf area hill ${ }^{-1}=$ mean leaf area of the middle tiller $x$ total number of tillers

5. Fresh strawyield $\left(\mathrm{tha}^{-1}\right)$. This was determined by weighing the harvested straws from 8 inner rows $\left(6.72 \mathrm{~m}^{2}\right)$, excluding two border rows at both sides and two end hills in each row. The straw yield per plot was converted into per hectare basis using the formula:

\begin{tabular}{|c|c|c|}
\hline \multirow{2}{*}{$\begin{array}{l}\text { Fresh } \\
\text { Straw } \\
\text { Yield } \\
\left(\mathrm{tha}^{-1}\right)\end{array}$} & $\begin{array}{c}\text { Plot } \\
\text { yield (kg) }\end{array}$ & \multirow{2}{*}{$\mathrm{x} \frac{10,000 \mathrm{~m}^{2} \mathrm{ha}^{-1}}{1,000 \mathrm{~kg} \mathrm{t}^{-1}}$} \\
\hline & $\begin{array}{c}\text { Harvestable } \\
\text { area } \\
\left(6.72 \mathrm{~m}^{2}\right)\end{array}$ & \\
\hline
\end{tabular}

\section{Yield and Yield Components}

1. Number of productive tillers per hill. This was recorded by counting the number of tillers of five sample plants that develop panicles in each treatment plot when 90\% of the panicles had matured.

2. Panicle length $(\mathrm{cm})$ at maturity. This was determined by measuring the length from the base up to the tip of ten sample panicles per treatment plot at maturity. The total length $(\mathrm{cm})$ of all sample panicles was divided by ten to get the average length of panicles.

3. Panicle weight (g). This was obtained by weighing each of the ten sample panicles per treatment plot. Total weight $(\mathrm{g})$ of the ten sample panicles was divided by ten to get the average weight of panicle.

4. Number of filled and unfilled grains per panicle. This was determined by counting the number of grains from the ten sample panicles obtained from each treatment plot. The total number of grains counted was divided by the ten sample panicles to get the average number of grains per panicle.

5. Weight of 1,000 grains (g). This was determined by weighing 1,000 grains taken at random from the sample panicles. The seeds were sun-dried and weighed when said seeds achieved at $14 \%$ moisture content (MC).

6. Grain yield $\left(\mathrm{t} \mathrm{ha}^{-1}\right)$. All the panicles in the inner rows were harvested and threshed. The grains were sun-dried for three days, and weighed when aforesaid grains attained at $14 \%$ moisture content. The weight per plot was converted into per hectare basis using the formula:

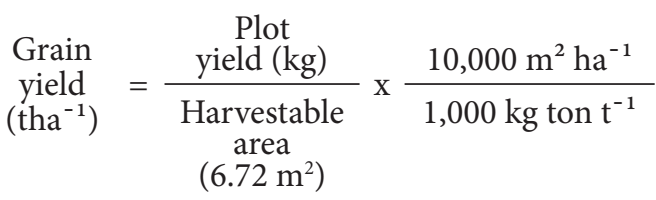

\section{Harvest Index (HI)}

This is the ratio between the economic yield (grain yield) and the biological yield (straw yield + grain yield) under dry weight basis. This indicates the plants efficiency to convert the absorbed nutrients and the product of photosynthesis into grains. Three sample plants were cut closer to the ground and the grains were placed in the paper bag. The chaff and straws were separated from the grains. The straws, and the grains were oven dried at $70^{\circ} \mathrm{C}$ until the weight becomes constant. The higher the harvest index means a higher grain 
yield relative to straw yield. On the other hand, low harvest index means more vegetative growth relative to the proportion of the grains formed. It was calculated using the formula:

$$
\begin{aligned}
& \text { Dry weight of grains } \\
& \mathrm{HI}=\frac{(\mathrm{g}) \text { three samples }}{\text { Dry straw yield }} \text { or } \frac{\text { Economic yield }}{\text { Biological yield }} \\
& (\mathrm{kg})+\text { Dry weight } \\
& \text { of grains }(\mathrm{g}) \text { three } \\
& \text { samples }
\end{aligned}
$$

\subsection{Results and Discussion}

\subsection{Soil Chemical Properties}

Initial soil analysistaken from the experimental area showed that the soil had the following chemical properties: $5.78 \mathrm{pH}, 4.18 \%$ organic matter, $0.11 \% \mathrm{~N}, 11.79 \mathrm{mg} \mathrm{kg}^{-1} \mathrm{P}$, and $0.488 \mathrm{me}$ $100 \mathrm{~g}^{-1} \mathrm{~K}$ (Table 2). The result revealed that the soil was moderately acidic, contained medium amount of organic matter, had a low amount in total $\mathrm{N}$, and had a high amount in both available phosphorus and exchangeable potassium (Landon, 1991).

The result of the final soil analysis revealed that an increase in soil $\mathrm{pH}$ was due to the slow utilization of organic fertilizers by the ratoon plants. This might be also due to the application of $\mathrm{N}$ fertilizer at a high rate of $90 \mathrm{~kg}$ ha- 1 as construed with the finding of Namoca, 2004. However, result conformed the statement of Ratilla and Cagasan (2011) that increase in soil pH could be attributed to the application of inorganic fertilizers, iron reducible in the soil, and suspension effect of flooded soils during vegetative growth and development of the main and ratoon crops. Besides, high availability of magnesium and calcium in the soil which primarily due to the decomposed stubbles of uprooted weeds also influences an increase in soil pH.

\subsection{Agronomic Characteristics}

Statistical analysis revealed that all agronomic characteristics (Table 3) were significantly affected by the different methods of nitrogen application except the fresh straw yield $\left(\mathrm{t} \mathrm{ha} \mathrm{h}^{-1}\right)$. Ratoon lowland rice applied with $60 \mathrm{~kg} \mathrm{ha}^{-1} \mathrm{~N}$ basal +30 $\mathrm{kg} \mathrm{ha}^{-1} \mathrm{~N}$ topdress $\left(\mathrm{T}_{3}\right)$ significantly headed earlier than those ratoon plants of other treatments, particularly unfertilized plants $\left(\mathrm{T}_{0}\right)$. Ratoon plants applied with inorganic fertilizer (urea) at different methods of $\mathrm{N}$ application such as treatments; $\mathrm{T}_{1}, \mathrm{~T}_{2}$ and $\mathrm{T}_{4}$ headed similarly and resulted in attributing significant differences with the unfertilized control plants $\left(\mathrm{T}_{0}\right)$.

Relative to its maturity, ratoon lowland rice applied with $90 \mathrm{~kg} \mathrm{ha}^{-1} \mathrm{~N}$ basal application ( $\mathrm{T}_{4}$ significantly delayed its maturity than those of the other treatments. This was followed by ratoon plants used with $30 \mathrm{~kg} \mathrm{ha}^{-1} \mathrm{~N}$ basal $+60 \mathrm{~kg} \mathrm{ha}^{-1} \mathrm{~N}$ topdress $\left(\mathrm{T}_{2}\right)$, but comparable to rice plants applied with $90 \mathrm{~kg} \mathrm{ha}^{-1}$ topdress application only $\left(\mathrm{T}_{1}\right)$. However, ratoon plants applied with $60 \mathrm{~kg}$ ha-1 $\mathrm{N}$ basal $+30 \mathrm{~kg} \mathrm{ha}^{-1} \mathrm{~N}$ topdress $\left(\mathrm{T}_{3}\right)$ were harvested significantly earlier than $\mathrm{T}_{2}$ and $\mathrm{T}_{4}$ but comparable to $T_{1}$ and matured considerably late than that of control plants $\left(T_{0}\right)$.

For plant height, taller growth was significantly noted in ratoon plants applied with a nitrogen fertilizer at the rate of $90 \mathrm{~kg} \mathrm{ha}^{-1}$ in two split applications, and also those ratoon plants applied with $90 \mathrm{~kg} \mathrm{ha}^{-1} \mathrm{~N}$ as the basal application only $\left(\mathrm{T}_{4}\right)$. However, ratoon plants applied with 90 $\mathrm{kg} \mathrm{ha}^{-1} \mathrm{~N}$ topdress application only $\left(\mathrm{T}_{1}\right)$ produced significantly shorter plant height of $101.47 \mathrm{~cm}$ comparing $T_{2}, T_{3}$, and $T_{4}$ but markedly taller than those of unfertilized ratoon plants $\left(T_{0}\right)$. For leaf area index (LAI), all fertilized ratoon plants, regardless of methods of $\mathrm{N}$ fertilization, significantly achieved 
higher LAI when compared to unfertilized ratoon plants ( $\left.T_{0}\right)$. Although ratoon plants under $T_{4}$ reached the highest $L A I$ (4.37), and $T_{3}, T_{2}$, and $T_{1}$ followed this with LAl values of 4.29, 3.57, and 3.35, respectively.

The result implied that plants applied of either $60 \mathrm{~kg} \mathrm{ha}^{-1} \mathrm{~N}$ basal $+30 \mathrm{~kg} \mathrm{ha}^{-1} \mathrm{~N}$ topdress ( $\left.T_{3}\right)$ and $90 \mathrm{~kg} \mathrm{ha}^{-1} \mathrm{~N}$ basal application ( $\mathrm{T}_{4}$ ) generally enhanced the agronomic characteristics such as plant height and leaf area index. This study corroborated with the finding of Patolilic (1988), who mentioned that high application rate of nitrogen in rice from 30 to $60 \mathrm{~kg} \mathrm{ha}^{-1}$ resulted in a significant increase in LAl. The finding conformed to the claim of Gonzaga (2006), which opined that the application of inorganic fertilizer to lowland rice significantly increased LAI and straw yield, and effectively provided available nutrients for rice plant's immediate utilization to enhance their growth and grain development (Lasco, 2017).

Table 2. Soil chemical properties of the soil before crop establishment then after harvest of ratoon lowland rice var. NSIC RC352 to the method of nitrogen application

\begin{tabular}{|c|c|c|c|c|c|}
\hline Treatment & $\begin{array}{l}\text { Soil pH } \\
\left(\mathrm{H}_{2} \mathrm{O}\right)\end{array}$ & $\begin{array}{l}\mathrm{OM} \\
(\%)\end{array}$ & $\begin{array}{c}\text { Total N } \\
(\%)\end{array}$ & $\begin{array}{l}\text { Available P } \\
\left(\mathrm{mg} \mathrm{kg}^{-1}\right)\end{array}$ & $\begin{array}{l}\text { Exchangeable } \\
\mathrm{K}\left(\mathrm{me} 100 \mathrm{~g}^{-1}\right)\end{array}$ \\
\hline \multicolumn{6}{|l|}{ Initial Soil Analysis } \\
\hline $\mathrm{T}_{0}=$ No fertilizer application (control) & 5.71 & 4.52 & 0.10 & 10.94 & 0.585 \\
\hline $\mathrm{T}_{1}=90 \mathrm{~kg} \mathrm{ha}^{-1} \mathrm{~N}$ topdress application only & 5.69 & 4.21 & 0.14 & 9.68 & 0.465 \\
\hline $\begin{array}{l}\mathrm{T}_{2}=30 \mathrm{~kg} \mathrm{ha}^{-1} \mathrm{~N} \text { basal }+60 \mathrm{~kg} \mathrm{ha}^{-1} \mathrm{~N} \\
\text { topdress }\end{array}$ & 5.89 & 4.21 & 0.11 & 14.90 & 0.458 \\
\hline $\begin{array}{l}\mathrm{T}_{3}=60 \mathrm{~kg} \mathrm{ha}^{-1} \mathrm{~N} \text { basal }+30 \mathrm{~kg} \mathrm{ha}^{-1} \mathrm{~N} \\
\text { topdress }\end{array}$ & 5.79 & 3.82 & 0.10 & 11.61 & 0.383 \\
\hline $\mathrm{T}_{4}=90 \mathrm{~kg} \mathrm{ha}^{-1} \mathrm{~N}$ basal application only & 5.82 & 4.13 & 0.09 & 11.80 & 0.550 \\
\hline Mean & 5.78 & 4.18 & 0.11 & 11.79 & 0.488 \\
\hline \multicolumn{6}{|l|}{ Final Soil Analysis } \\
\hline $\mathrm{T}_{0}=$ No fertilizer application (control) & 5.62 & 4.75 & 0.24 & 14.82 & 0.630 \\
\hline $\mathrm{T}_{1}=90 \mathrm{~kg} \mathrm{ha}^{-1} \mathrm{~N}$ topdress application only & 5.89 & 4.99 & 0.25 & 17.34 & 0.730 \\
\hline $\begin{array}{l}\mathrm{T}_{2}=30 \mathrm{~kg} \mathrm{ha}^{-1} \mathrm{~N} \text { basal }+60 \mathrm{~kg} \mathrm{ha}^{-1} \mathrm{~N} \\
\text { topdress }\end{array}$ & 5.88 & 5.46 & 0.26 & 16.68 & 0.623 \\
\hline $\begin{array}{l}\mathrm{T}_{3}=60 \mathrm{~kg} \mathrm{ha}^{-1} \mathrm{~N} \text { basal }+30 \mathrm{~kg} \mathrm{ha}^{-1} \mathrm{~N} \\
\text { topdress }\end{array}$ & 5.90 & 5.304 & 0.26 & 20.40 & 0.595 \\
\hline $\mathrm{T}_{4}=90 \mathrm{~kg} \mathrm{ha}^{-1} \mathrm{~N}$ basal application only & 5.93 & 5.148 & 0.26 & 21.10 & 0.531 \\
\hline Mean & 5.84 & 5.13 & 0.26 & 18.07 & 0.622 \\
\hline
\end{tabular}


Table 3. Agronomic characteristics of ratoon lowland rice var. NSIC RC352 to method of nitrogen application

\begin{tabular}{|c|c|c|c|c|c|}
\hline \multirow{2}{*}{ Treatment } & \multicolumn{2}{|c|}{$\begin{array}{l}\text { No. of days from harvesting } \\
\text { the main plant until }\end{array}$} & \multirow{2}{*}{$\begin{array}{l}\text { Plant height } \\
\quad(\mathrm{cm})\end{array}$} & \multirow{2}{*}{$\begin{array}{c}\text { Leaf area } \\
\text { index } \\
\text { (LAI) }\end{array}$} & \multirow{2}{*}{$\begin{array}{l}\text { Fresh straw } \\
\text { yield }\left(\mathrm{t} \mathrm{ha}^{-1}\right)\end{array}$} \\
\hline & Heading & Harvesting & & & \\
\hline $\begin{array}{l}\mathrm{T}_{0}=\text { No fertilizer application } \\
\text { (control) }\end{array}$ & $58.00 \mathrm{c}$ & $78.00 \mathrm{~d}$ & $91.97 \mathrm{c}$ & $1.09 \mathrm{~b}$ & 8.00 \\
\hline $\begin{array}{l}\mathrm{T}_{1}=90 \mathrm{~kg} \mathrm{ha}^{-1} \mathrm{~N} \text { topdress } \\
\text { application only }\end{array}$ & $60.67 \mathrm{~b}$ & $80.00 \mathrm{bc}$ & $101.47 \mathrm{~b}$ & $3.35 \mathrm{a}$ & 17.09 \\
\hline $\begin{array}{l}\mathrm{T}_{2}=30 \mathrm{~kg} \mathrm{ha}^{-1} \mathrm{~N} \text { basal }+60 \mathrm{~kg} \\
\text { ha }^{-1} \mathrm{~N} \text { topdress }\end{array}$ & $61.33 \mathrm{~b}$ & $80.33 \mathrm{~b}$ & $112.27 \mathrm{a}$ & $3.57 \mathrm{a}$ & 21.19 \\
\hline $\begin{array}{l}\mathrm{T}_{3}=60 \mathrm{~kg} \mathrm{ha}^{-1} \mathrm{~N} \text { basal }+30 \mathrm{~kg} \\
\text { ha }^{-1} \mathrm{~N} \text { topdress }\end{array}$ & $62.67 \mathrm{a}$ & $79.67 \mathrm{c}$ & $116.17 \mathrm{a}$ & $4.29 \mathrm{a}$ & 12.65 \\
\hline $\begin{array}{l}\mathrm{T}_{4}=90 \mathrm{~kg} \mathrm{ha}^{-1} \mathrm{~N} \text { basal } \\
\text { application only }\end{array}$ & $61.00 \mathrm{~b}$ & $81.00 \mathrm{a}$ & $115.00 \mathrm{a}$ & $4.37 \mathrm{a}$ & 20.58 \\
\hline Mean & 60.73 & 79.80 & 107.37 & 3.33 & 15.89 \\
\hline CV (\%) & 1.02 & 0.43 & 4.24 & 16.46 & 34.59 \\
\hline
\end{tabular}

3.3 Yield and Yield Components and Harvest Index

Results on yield and yield components and harvest index of ratoon lowland rice NSIC Rc352 revealed that the weight of 1,000 grains, harvest index, and grain yield ( $\left(\mathrm{tha}^{-1}\right)$ did not significantly affect the different methods of $\mathrm{N}$ application tested (Table 4). On the other hand, the number of productive tillers per hill, panicle length $(\mathrm{cm})$, panicle weight $(\mathrm{g})$, number of filled and unfilled grains per panicle showed significant effect by the different methods of nitrogen application adopted.

Plants applied with $60 \mathrm{~kg} \mathrm{ha}^{-1} \mathrm{~N}$ basal +30 $\mathrm{kg} \mathrm{ha}^{-1} \mathrm{~N}$ topdress $\left(\mathrm{T}_{3}\right)$ produced a higher number of productive tillers hill-1 than the control plants. Other fertilized treatments such as $T_{1}, T_{2}$, and $T_{4}$ had a statistically similar number of productive tillers to those ratoon plants applied with $60 \mathrm{~kg} \mathrm{ha}^{-1}$ basal $+30 \mathrm{~kg} \mathrm{ha}^{-1}$ topdress. The result implied that in achieving higher productive tillers hill-1 ${ }^{-1}$ it would be appropriate to use $\mathrm{N}$ nutrient at the rate of 90 $\mathrm{kg}$ ha-1 regardless of methods of application.

The yield components such as panicle length, panicle weight (g), number of filled and unfilled grains per panicle exhibited similar trends with the number of productive tillers as influenced by the different methods of $\mathrm{N}$ application. The result confirmed the finding of Baoy and Bañoc (2017). The researchers revealed that the availability of nitrogen provided by inorganic fertilizer contributed significantly to increase growth and development of rice plants that led to enhance the production of tillers, longer and heavier panicles, more developed grains, and higher grain yield. Thereby, this finding also construed with the study of Sorita (1993), which mentioned that nitrogen application enhanced the development of longer and heavier panicles that eventually resulted in higher grain yield of rice hectare-1. 
Table 4. Yield and yield components of ratoon lowland rice var. NSIC Rc352 to method of nitrogen application

\begin{tabular}{|c|c|c|c|c|c|c|c|c|}
\hline Treatment & $\begin{array}{l}\text { No. of } \\
\text { productive } \\
\text { tillers per } \\
\text { hill }\end{array}$ & $\begin{array}{l}\text { Panicle } \\
\text { length } \\
(\mathrm{cm})\end{array}$ & $\begin{array}{l}\text { Panicle } \\
\text { weight } \\
\text { (g) }\end{array}$ & $\begin{array}{l}\text { No. of } \\
\text { filled } \\
\text { grains per } \\
\text { panicle }\end{array}$ & $\begin{array}{l}\text { No. of } \\
\text { unfilled } \\
\text { grains per } \\
\text { panicle }\end{array}$ & $\begin{array}{l}\text { Weight } \\
\text { of } 1,000 \\
\text { grains (g) }\end{array}$ & $\begin{array}{l}\text { Grain } \\
\text { yield } \\
\left(\mathrm{t} \mathrm{ha}^{-1}\right)\end{array}$ & $\begin{array}{l}\text { Harvest } \\
\text { Index }\end{array}$ \\
\hline $\mathrm{T}_{0}=$ Control & $9.13 \mathrm{~b}$ & $21.77 \mathrm{~b}$ & $13.77 \mathrm{~b}$ & $53.00 \mathrm{~b}$ & $17.40 \mathrm{~b}$ & 23.27 & 1.15 & 0.45 \\
\hline $\begin{array}{l}\mathrm{T}_{1}=90 \mathrm{~kg} \mathrm{ha}^{-1} \mathrm{~N} \\
\text { topdress application } \\
\text { only }\end{array}$ & $16.00 \mathrm{a}$ & $25.82 \mathrm{a}$ & $23.23 \mathrm{a}$ & $88.47 \mathrm{a}$ & $28.07 \mathrm{a}$ & 23.93 & 1.45 & 0.52 \\
\hline $\begin{array}{l}\mathrm{T}_{2}=30 \mathrm{~kg} \mathrm{ha}^{-1} \mathrm{~N} \\
\text { basal }+60 \mathrm{~kg} \mathrm{ha}^{-1} \mathrm{~N} \\
\text { topdress }\end{array}$ & $17.87 \mathrm{a}$ & $26.17 \mathrm{a}$ & $24.47 \mathrm{a}$ & $94.77 \mathrm{a}$ & $32.23 \mathrm{a}$ & 24.00 & 2.21 & 0.50 \\
\hline $\begin{array}{l}\mathrm{T}_{3}=60 \mathrm{~kg} \mathrm{ha}^{-1} \mathrm{~N} \\
\text { basal }+30 \mathrm{~kg} \mathrm{ha}^{-1} \mathrm{~N} \\
\text { topdress }\end{array}$ & $18.53 \mathrm{a}$ & 25.39 a & $22.80 \mathrm{a}$ & $88.83 \mathrm{a}$ & $31.50 \mathrm{a}$ & 24.00 & 2.32 & 0.44 \\
\hline $\begin{array}{l}\mathrm{T}_{4}=90 \mathrm{~kg} \mathrm{ha}^{-1} \mathrm{~N} \\
\text { basal application } \\
\text { only }\end{array}$ & $18.27 \mathrm{a}$ & $26.04 \mathrm{a}$ & $25.73 \mathrm{a}$ & $94.17 \mathrm{a}$ & $30.50 \mathrm{a}$ & 24.83 & 1.85 & 0.49 \\
\hline Mean & 15.96 & 25.04 & 22.00 & 83.95 & 27.94 & 24.01 & 1.80 & 0.48 \\
\hline CV (\%) & 12.02 & 3.85 & 12.59 & 11.67 & 15.74 & 3.45 & 30.01 & 11.82 \\
\hline
\end{tabular}

The result of the study implied that split application of nitrogen at $60 \mathrm{~kg} \mathrm{ha}{ }^{-1} \mathrm{~N}$ basal $+30 \mathrm{~kg}$ $\mathrm{ha}^{-1} \mathrm{~N}$ topdress $\left(\mathrm{T}_{3}\right)$ was appropriate and the best method for ratooning of lowland rice to gain high profit for the rice farmers. However, the other better method of fertilization was the split application of $\mathrm{N}$ fertilizer following $30 \mathrm{~kg} \mathrm{ha}^{-1}$ applied as basal. In comparison, the remaining $\mathrm{N}$ of $60 \mathrm{~kg} \mathrm{ha}^{-1}$ was applied as topdressing to the ratoon plants (T2). Plants used with $60 \mathrm{~kg} \mathrm{ha}^{-1} \mathrm{~N}$ basal $+30 \mathrm{~kg} \mathrm{ha}^{-1} \mathrm{~N}$ topdress $\left(T_{3}\right)$ gave a higher number of productive tillers hill-1 than the control plants. The rest of the fertilized treatments, i.e., $T_{1}, T_{2}$, and $T_{4}$, produced statistically similar on the number of productive tillers to those ratoon plants applied with $60 \mathrm{~kg} \mathrm{ha}^{-1}$ basal $+30 \mathrm{~kg} \mathrm{ha}^{-1}$ topdress. The result suggested that for higher productive tillers per hill, it was appropriate to use $\mathrm{N}$ nutrient at the rate of $90 \mathrm{~kg}$ $\mathrm{ha}^{-1}$ regardless of methods of application. The yield components such as panicle length $(\mathrm{cm})$, panicle weight ( $g$ ), number of filled and unfilled grains per panicle exhibited the same trends with the number of productive tillers as influenced by the different methods of $\mathrm{N}$ application.

\subsection{Cost and Return Analysis}

Cost and return analysis of growing ratoon lowland rice NSIC Rc352 showed that ratoon plants applied with $60 \mathrm{~kg} \mathrm{ha}^{-1} \mathrm{~N}$ basal $+30 \mathrm{~kg}$ ha ${ }^{-1} \mathrm{~N}$ topdress $\left(T_{3)}\right.$ gave higher gross income and gross margin of PhP 48,600.00 and PhP 25,564.80, respectively (Table 5). The plants applied with the split application of nitrogen at the rate of 30 kg ha-1 $\mathrm{N}$ basal $+60 \mathrm{~kg} \mathrm{ha}^{-1} \mathrm{~N}$ topdress $\left(\mathrm{T}_{2}\right)$ with 
a gross income of $\mathrm{PhP} 44,200.00$ and also with a gross margin of PhP 21,010.80.

On the other hand, unfertilized control plants $\left(T_{0}\right)$ obtained the lowest gross income. However, it did not provide the lowest gross margin since the total variable cost incurred was the lowest among the treatments tested. Ratoon plants applied with
$90 \mathrm{~kg} \mathrm{ha}^{-1} \mathrm{~N}$ topdress application only $\left(\mathrm{T}_{1}\right)$ gave the lowest gross margin of $\mathrm{PhP} 7,980.80$ even if this treatment attributed a considerable higher gross income of PhP 29,000.00 compared to unfertilized ratoon plants $\left(\mathrm{T}_{0}\right)$ with a gross income of $\mathrm{PhP}$ $23,000.00$

Table 5. Cost and return analysis of ratoon lowland rice var. NSIC Rc352 to method of nitrogen application

\begin{tabular}{lcccc}
\hline \multicolumn{1}{c}{ Treatment } & $\begin{array}{c}\text { Grain yield } \\
\left(\mathrm{t} \mathrm{ha}^{-1}\right)\end{array}$ & $\begin{array}{c}\text { Gross income } \\
(\mathrm{PhP}) \\
\left(\mathrm{t} \mathrm{ha}^{-1}\right)\end{array}$ & $\begin{array}{c}\text { Total variable } \\
\text { cost }(\mathrm{PhP}) \\
\left(\mathrm{t} \mathrm{ha}^{-1}\right)\end{array}$ & $\begin{array}{c}\text { Gross margin } \\
(\mathrm{PhP}) \\
\left(\mathrm{t} \mathrm{ha}^{-1}\right)\end{array}$ \\
\hline $\mathrm{T}_{0}=$ No fertilizer application (control) & 1.15 & 23,000 & $6,880.00$ & $16,120.00$ \\
$\mathrm{~T}_{1}=90 \mathrm{~kg} \mathrm{ha}^{-1} \mathrm{~N}$ topdress application only & 1.45 & 29,000 & $21,019.20$ & $7,980.80$ \\
$\mathrm{~T}_{2}=30 \mathrm{~kg} \mathrm{ha}^{-1} \mathrm{~N}$ basal + 60 $\mathrm{kg} \mathrm{ha}^{-1} \mathrm{~N}$ & 2.21 & 44,200 & $22,989.20$ & $21,010.80$ \\
topdress & & & & \\
$\begin{array}{l}\mathrm{T}_{3}=60 \mathrm{~kg} \mathrm{ha}^{-1} \mathrm{~N} \text { basal + } 30 \mathrm{~kg} \mathrm{ha}^{-1} \mathrm{~N} \\
\text { topdress }\end{array}$ & 2.43 & 48,600 & $23,035.20$ & $25,564.80$ \\
$\mathrm{~T}_{4}=90 \mathrm{~kg} \mathrm{ha}^{-1} \mathrm{~N}$ basal application only & 1.85 & 37,000 & $21,899.20$ & $15,100.80$ \\
\hline
\end{tabular}

The result of the study implied that split application of nitrogen at $60 \mathrm{~kg} \mathrm{ha}^{-1} \mathrm{~N}$ basal + $30 \mathrm{~kg} \mathrm{ha}^{-1} \mathrm{~N}$ topdress $\left(\mathrm{T}_{3}\right)$ was appropriate and the best method for ratooning of lowland rice to gain high profit for the ratoon growers. However, the other better option of fertilization was the split application of $\mathrm{N}$ fertilizer following $30 \mathrm{~kg} \mathrm{ha}^{-1}$ applied as basal. In contrast, the remaining $\mathrm{N}$ of 60 $\mathrm{kg} \mathrm{ha}^{-1}\left(\mathrm{~T}_{2}\right)$ used as topdressed to the ratoon plants.

\subsection{Conclusion}

Rice ratooning is one of the mitigation measures to the ill-effects of climate change and unforeseen climatic conditions. This is because ratoon growers produced additional rice production and income particularly during the lean months. In this context, rice ratooning adopting split application of nitrogen enhances the plant height of ratoon plants, and apparently produces higher grain yield of ratoon crop; thus, answering the abovementioned problematic situation. Ratoon rice plants applied with $60 \mathrm{~kg}$ $\mathrm{ha}^{-1} \mathrm{~N}$ basal $+30 \mathrm{~kg} \mathrm{ha}^{-1} \mathrm{~N}$ topdress $\left(\mathrm{T}_{3}\right)$ achieves a high grain yield of $2.43 \mathrm{t}$ ha- 1 and provides the highest gross margin of PhP 25,564.80 comparing all other treatments. This practice can compensate the cost of production vis-a-vis the growing period of ratoon crop. In fact, ratoon crop in $\mathrm{T}_{3}$ with gross margin of PhP 25,564.80 has an expected daily income of $\mathrm{PhP} 511.30$ reflecting 50 days of the 
growing period of ratoon crop while only $\mathrm{PhP}$ 422.61 per day for the main crop with gross margin of $\mathrm{PhP} 48,600$ and a growing period of 115 days from sowing. Thereby, in enhancing productivity of ratoon crop, split application of nitrogen at the rate of $60 \mathrm{~kg} \mathrm{ha}^{-1} \mathrm{~N}$ basal $+30 \mathrm{~kg} \mathrm{ha}^{-1} \mathrm{~N}$ topdress is an appropriate method of nitrogen application that provides higher grain yield and income for the ratoon growers.

\section{References}

Aulakh, M., Khera, T.S., Doran, J.W., Singh, K. \& Singh, B. (2000). Yield under nitrogen dynamics in a rice-wheat system using green manure and inorganic fertilizer. Soil Sci. Soc. in America Journal, 64, 1867 - 1876. https://doi. org/10.2136/sssaj2000.6451867x

Baoy, R.A. \& Bañoc, D.M. (2017). Performance of inbred and hybrid rice (Oryza sativa L.) varieties as influenced by the combined application of organic and inorganic fertilizers. Annals of Tropical Research 39(1), 70 - 85. https://doi.org/10.32945/atr3915.2017

Castillejo Sanchez, M.A., Kirchev, H. \& Jorrin, J.V. (2010). Differences in the Triticale (X Triticosecale Wittmack) Flag Leaf 2-DE Protein Profile between Varieties and Nitrogen Fertilization Levels. Journal of Agricultural and Food Chemistry, 58(9), 5698 - 5707. https:// doi.org/10.1021/jf100215t

Clatterbuck, W.K. (1914). Nutrient deficiencies in trees. Agricultural Extension Service. The University of Tennessee, Institute of Agriculture, Division of Forestry, U. S.
Department of Agriculture.

Elias, R.S. (1969). Rice production through minimal tillage. Outlook Agric, 6(2), 67 - 70. https://doi. org/10.1177/003072706900600204

Fageria, N.K. \& Baligar, V.C. (1996). Lowland rice response to $\mathrm{N}$ fertilization. Comm. Soil Sci. Plant Anal., 32, 1405 - 1429. https://doi. org/10.1081/CSS-100104202

Fageria, N.K., Baligar, V.C. \& Jones, C.A. (1997). Growth through nutrition of field crops (2nd ed.). Marcel Dekkar.

Fernandez, M.O. (1991). Response of three upland rice varieties to nitrogen fertilizer [Unpublished - Undergraduate Thesis]. Leyte State University.

Gomez, K.A. \& Gomez, A.A. (1976). Statistical Procedures for Agricultural Research (2nd ed.). John Wiley and Sons.

Gonzaga, D.A. (2006). Effects of combined cattle manure and inorganic fertilizer on lowland rice [Unpublished - Undergraduate Thesis]. Leyte State Universiy.

Kundu, D.K., Ladha, J.K. \& Lapitan-De-Guzman E. (1996). Tillage depth influence on soil nitrogen distribution and availability in a rice lowland. Soil Sci. Soc. Am. J. 60, 1153-1159.https://doi.org/10.2136/ sssaj1996.03615995006000040028x

Landon, J.R. (1991). Booker tropical soil manual: A handbook for soil survey and agricultural land 
evaluation in both tropics and subtropics. Long Scientific and Technical John Wiley and Sons, Inc.

Lasco, V.P. (2017). Performance of lowland red rice (Oryza sativa L.) as influenced by the combined application of organic and inorganic fertilizers. [Unpublished-Undergraduate Thesis]. Visayas State University.

Namoca, J.M. (2004). Response of upland rice to various rates of nitrogen application. [Unpublished-Undergraduate Thesis]. Leyte State University.

Patolilic, R. G. (1988). Growth, yield of upland rice as affected by different methods of planting and levels of nitrogen fertilizer [Unpublished Undergraduate Thesis]. Leyte State University.

Plucknett, D.L., Enenson, J.P. \& Sanford, W.G. (1970). Ratoon cropping. Adv. Agron. 22, 285-330. https://doi.org/10.1016/S00652113(08)60271-0

Ratilla, M.D. \& Cagasan, U.A. (2011). Growth and yield performance of selected lowland rice varieties under alternative wet and dry water management. Annals of Tropical Research. 33(2), 130 - 142. https://doi.org/10.32945/ $\operatorname{atr} 3327.2011$

Samson, B.T. (1980). Rice ratooning: Effects of varietal type and some cultural management practices. [Unpublished - Master's Thesis]. University of the Philippines Los Baños, Laguna, Philippines.
Sorita, M.Z. (1993). Effects of planting time, nitrogen levels on the growth and yield response of upland rice. [Unpublished - Undergraduate Thesis]. Leyte State University.

Yoshida, S. (1981). Fundamentals of Rice Crop Science. International Rice Research Institute.

Zhu, Z. \& Chen, D. (2002). Nitrogen fertilizer use as a significant contribution to food production, impacts on the environment and best management strategies. Nutr. Cycl. Agroecosystem, 63, 117 - 27. https://doi. org/10.1023/A:1021107026067 